\title{
The Whirling Dervishes: An Old Heritage Recognized at Last
}

\author{
Ikrame Selkani* \\ University Mohammed V-Rabat-Morocco \\ Submission: March 26, 2018; Published: September 05, 2018 \\ *Corresponding author: Ikrame Selkani, University Mohammed V Rabat, Morocco, Email: ikrame.selkani@gmail.com
}

\begin{abstract}
The latter owe their name to their prayer which practices it following the Sufi order. It is a dance to awaken the curiosity of different people from all four corners of the world to admire this show. Hence the beginning of a tourism with culture and art that will be called cultural tourism in the city of Konya in Turkey.
\end{abstract}

Keywords: Whirling Dervishes; Turkey; Mevlana; Cultural Touris; Mevlevi; Konya

\section{Introduction}

In the $13^{\text {th }}$ century, the great thinker of Sufism, Jalal DIN Rûmî, blends in the Mevlevi's order in Konya, a city in Turkey. The members of the Mevlevi's order are called "the whirling dervishes" which bears this name due to the movement of their dance. This dance is performed during a ceremony called "Sema", during which whirling dervishes perform rotations on themselves more and more quickly following the sound of traditional music. Konya, the largest crossroads city in the world, home to more than a million inhabitants, located at the center of many religions, became a very important place, a sort of pilgrimage since the remains of the founder of the Order of the Mevlevis lies there. From the mausoleum to the museum of Mevlana and the manifestation of whirling dervishes in the city of Konya especially Turkey, the issue of tourism tends to become a little more cultural.

\section{Whirling Dervishes: An Old Discipline Finally Recog- nized}

The whirling dervishes are also known as the Mevlevi and well known in the city of Konya, Turkey. Ancient and mystical city where lies one of the great poets, Jalal DIN Rumi. Nowadays the tomb of this man has become a great touristic site in the city of Konya, the second known touristic place after the Topkapi Palace in Istanbul. This city includes mausoleum where the mausoleum of Mevlâna which is the source of Sufism. During the ceremonies, the Mevlevis slowly begins their show with three turns while walking: the first round symbolizes the creation of the sun, the moon, and the stars by God; the second round represents the creation of plants, and the third represents the creation of animals. The Whirling Dervishes moves to the middle of the room with arms crossed and their hands on their shoulders. The
Mevlevis owe their names to their prayers. The whirling dervish performs a dance following a traditional music while turning on himself. The Mevlevi unfold his arms to then raise them to the sky. Deploying the palm of the left hand towards the sky and the palm of the right hand towards the ground. The Mevlevis rotate on themselves by leaning on the left foot and the right foot is used to rotate. Hence, flexibility is recommended, the eyes remain wide open without fixating anything to prevent the sightfrom becoming blurred. The movement settled in the 13th century in Turkey by Jalal DIN Rûmî Persian poet and philosopher joined the mystical branch: Sufism.

\section{7-1273, Jalal Din Rûmî was the First to Practice} Whirling Dance

A religious man professes a mysticism about love and tolerance without distinction of culture or religion. The first whirling dervishes made their appearances dressed all in white and accompanied by music and songs. The Mevlana Museum in Konya is a former convent of whirling dervishes that has become a museum of Islamic art today. The latter could be described by a ceramic-covered tower and a mausoleum that attracts people each year. Well known by the name of "green mausoleum" because of the color of its dome. The museum contains a library, a school and the hall where rituals were practiced when the museum was still a convent. In the center, the mausoleum is generously decorated with Islamic writing and different enamel relief. It contains the remains of several important figures of the Mevlevi order. The main tomb is protected by a small silver gate from the end of the $16^{\text {th }}$ century and that of Mevlana Rumi. The room located next to the mausoleum now serves as a museum to expose many musical instruments used during dancing prayers, 
dresses that belonged to Mevlana as well as Ottoman items from the13th century engraved in gold. And among all these priceless items is found the most expensive silk carpet in the world [1-3].

The whirling dervish show is one of the things you cannot miss during a trip to Turkey. Konya remains the must-see city and a place that impregnates long mystical dance movement. Deeply anchored in the Turkish traditions, the movement of whirling dervishes is itself by its dynamism and its mystical aspect. Istanbul also organizes shows which areopen to everyone. When we talk about cultural tourism, we are talking about two worlds: culture and tourism. Both concepts together give birth to a new notion namely: Discovery.We travel to change ideas to de-stress. During the trip, we live the culture by visiting places that tell us the story through the historical places and revealing ancient civilizations, which for us today we can interpret as a renaissance and discovery. The cultural tourism is then combined in the form of all traditions artistic event and experience that represents a nation and reflects the diversity and cultural diversity of it. These lived experiences can be intellectual, emotional, aesthetics, etc. by attending to the different cultural products existing in this nation. Cultural tourism is a intense contact created in the traveler as soon as he is in the territory. Cultural tourism can be either a primary or secondary goal. In general, cultural tourists have a great interest in adventure and openness, they are very curious and have a great desire to share.

\section{Ritual of Sema}

The fundamental condition of our existence is to turn. There is no object, no being that does not turn. The shared similarity between all created things is the revolution of electrons, protons, and neutrons in the atoms that constitute their basic structure. From the smallest cell to the planets and the farthest stars, everything takes part in this rotation. Thus, Semazens, those who swirl, participate consciously in the shared revolution of all existence. The Sema ceremony represents a spiritual journey; the seeker turns to God and truth, love through love, selftransformation as a means of union with God and a return to life as a servant of all creation.

The Semazen (with a camel felt hat depicting a gravestone and a large white skirt symbolizing the shroud of death), after removing its black cloth, is spiritually born to the Truth. The Semazens stand with arms folded, ready to begin their turn. In their erect position, they represent the number one, testifying to the unity of God. Each rotation passes them in front of the sheik, who stands on a red sheepskin. This is the place of Mevlana Celaleddin-i Rumi, and the sheik is understood as a channel for divine grace. At the beginning of each of the four movements of the ceremony, the Semazens intrude upon each other respecting the inner spirit. As their arms unfold, the right hand opens to heaven in prayer, ready to receive the benevolence of God. The left hand, on which rests his eyes, is turned towards the ground in the gesture of agreement.

Fix-footed, the Semazen provides a point of contact with this Earth through which divine blessings can flow. Turning from right to left, he embraces all creation as he sings the name of God in his heart. The Sema ritual consists of seven parts: It begins with the singing of Nat-i-Serif, a eulogy for the Prophet Muhammad PBUH (peace be upon him), which represents love. The praiser praises the truth of God that he and all the prophets before him have brought. Then follows the call of the drum and the death knell of glory, calling the denizens to wake up and Be. This begins the procession known as Sultan Veled Walk. It is the greeting from one soul to another, recognized by the training.

Then begins the Sema ritual itself. It consists of four greetings or hello. The first selam is the birth of truth through knowledge. The second selam expresses a delight to attend the splendor of creation. The third selam is the transformation of rapture into love; the sacrifice of the mind and of oneself to love. It represents complete submission and communion with God. The fourth selam is the semazen's approach with his destiny and his return to his task in creation. In the fourth selam, the sheik enters the circulating dervishes, where he assumes the place of the sun in the center of the circulating planets. Sema ends with a reading of the Qur'an. The sheik and the dervishes complete their time with the greeting of peace, then leave, accompanied by a joyous music of their departure. One of the beauties of this seven-century ritual is how it unifies the three fundamental components of man's nature; mind, emotion, and spirit, combining them into one practice and a worship that seeks the purification of the three in the turning toward divine unity. But above all, the enrichment of this land and the well-being of humanity [4-6].

\section{References}

1. Feldman W (2002) Music in Performance: Who Are the Whirling Dervishes? The Garland encyclopedia of world music : the Middle East $6: 107-111$.

2. Friedlander S (1975) The whirling dervishes: being an account of the Sufi order known as the Mevlevis and its founder the poet and mystic Mevlana Jalalu'ddin Rumi. SUNY Press, New York, USA.

3. Friedlander S, Uzel N (1992) The Whirling Dervishes: Being an Account of the Sufi Order Known as the Mevlevis and Its Founder the Poet and Mystic Mevlana Jalalu'ddin Rumi (SUNY Series in Islam). State University of New York Press, USA.

4. Friedlander S Nasr SH, Uzel N (2003) Rumi and the whirling dervishes. Parabola Books, USA.

5. Rigby J (2005) A Turkish Interlacing Pattern and the Golden Ratio: Whirling Dervishes and a Geometry Lecture in Konya. Mathematics in School 34(1): 16-24.

6. Seabrook WB (1927) Adventures in Arabia: Among the Bedouins, Druses, Whirling Dervishes, \& Yezidee Devil Worshipers. Harcourt, Brace and company, USA. 
This work is licensed under Creative Commons Attribution 4.0 License

DOI: 10.19080/ASM.2018.01.555567
Your next submission with Juniper Publishers will reach you the below assets

- Quality Editorial service

- Swift Peer Review

- Reprints availability

- E-prints Service

- Manuscript Podcast for convenient understanding

- Global attainment for your research

- Manuscript accessibility in different formats

( Pdf, E-pub, Full Text, Audio)

- Unceasing customer service

Track the below URL for one-step submission https://juniperpublishers.com/online-submission.php 